\title{
A Case of Accessory Parotid Cyst Treated with Ultrasound-Guided Percutaneous Ethanol Injection
}

\author{
Moon Seung Beag', Beom Mo Koo ${ }^{1}$, Mi Ji Lee ${ }^{2}$, and Seung Woo Kim ${ }^{1}$ (D) \\ ${ }^{1}$ Departments of Otorhinolaryngology-Head and Neck Surgery, ${ }^{2}$ Pathology, Veterans Health Service Medical Center, Seoul, Korea
}

\author{
초음파 유도하 경피적 에탄올 주입술로 치료한 부이하선 낭종 1 예 \\ 백문승 ${ }^{1} \cdot$ 구범모 $^{1} \cdot$ 이미지 ${ }^{2} \cdot$ 김승우 $^{1}$ \\ 중앙보훈병원 이비인후과, ${ }^{1}$ 병리학과 ${ }^{2}$
}

\author{
Received March 27, 2020 \\ Revised April 26,2020 \\ Accepted May 4, 2020 \\ Address for correspondence \\ Seung Woo Kim, MD \\ Department of Otolaryngology- \\ Head and Neck Surgery, \\ Veterans Health Service \\ Medical Center, \\ 53 Jinhwangdo-ro 61-gil, \\ Gangdong-gu, Seoul 05368, Korea \\ Tel $+82-2-2225-1384$ \\ Fax $+82-2-2225-1385$ \\ E-mail entzzang1020@daum.net
}

\begin{abstract}
A cyst in the accessory parotid gland (APG) is extremely rare, with only three cases having been reported recently in English literature. They were all treated with sclerotherapy, where a cyst may appear as a painless superficial mass in the mid-cheek area. In sclerotherapy, the most commonly used materials are ethanol and OK-432, which report good therapeutic results for the treatment of benign cervical cystic mass. An 85-year-old man came to our clinic with superficial, well-margined ovoid mass on the left cheek. The mass was diagnosed as a benign cyst in APG through imaging studies and core needle biopsy. We performed the ultrasoundguided percutaneous ethanol injection and the cyst disappeared, leaving only the fused cystic wall. We report this very rare and interesting case with a literature review.
\end{abstract}

Korean J Otorhinolaryngol-Head Neck Surg 2020;63(6):282-5

Key Words Parotid gland · Cysts · Ethanol.

\section{서 론}

부이하선은 이하선 전방으로 교근의 표층에서 이하선관을 따라서 존재하는 독립된 타액선 조직으로, 이 부위의 종양은 협부의 표재성 종물로 나타날 수 있다. ${ }^{1,2)}$ 에탄올 또는 $\mathrm{OK}-432$ 등에 의한 경화 요법은 두경부 양성 낭종성 종물의 치료에 좋 은 결과를 보고하고 있다. ${ }^{3)}$ 부이하선 낭종은 그 발생 빈도가 매우 드물고, 경화요법으로 치료된 경우는 보고되지 않았다.

저자들은 좌측 협부의 낭성 종물을 주소로 내원한 부이하 선 낭종 환자에서 초음파 유도하에 에탄올 주입술로 좋은 치 료 결과를 보인 희귀 증례를 경험하여 문헌고찰과 함께 보고 한다.

This is an Open Access article distributed under the terms of the Creative Common Attribution Non-Commercial License (https://creativecommons.org/licenses/by-nc/4.0) which permits unrestricted non-commercial use, distribution, and reproduction in any medium, provided the original work is properly cited.

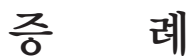

85세 남자 환자가 내원 2년 전부터 인지된 좌측 중간 협부 의 종물이 최근에 크기가 증가하여 본과로 내원하였다. 신체 검사에서 종물은 $1.6 \times 1.4 \mathrm{~cm}$ 크기의 경계가 명확한 무통성의 표재성 종물이었고(Fig. 1A), 좌측 안면부의 혈관종 외에 비 정상적으로 촉지되는 경부 종물은 없었다. 심근경색, 뇌경색 및 만성 신부전 등의 병력이 있으며, 음주력은 2주에 1회 소 주 1 병 정도였고, 흡연력은 없었다.

영상 평가를 위해 시행한 초음파 검사에서 교근의 천층에 $1.8 \times 1.4 \times 0.4 \mathrm{~cm}$ 크기의 뚜렷한 저에코 음영을 보이는 난원 형 종물이 관찰되었다(Fig. $2 \mathrm{~A})$. 전산화단층촬영에서는 동일 한 위치에 $2.0 \times 1.3 \times 1.8 \mathrm{~cm}$ 크기의 조영 증강되지 않는 저음 영 종물이 보였다(Fig. $2 \mathrm{~B}$ and $\mathrm{C}$ ). 조직학적 진단을 위해서 초음파 유도하에 종물 내부의 액체를 흡인하고, 낭벽 주변과 고형 성분으로 판단되는 부위에서 중심 생검을 시행하여 "분 
절된 소수의 침샘 조직"으로 보고 받았다. 환자의 연령, 전신 상태 및 수술 합병증 등을 고려하여 에탄올 경화 요법을 시 행하기로 하였다. 중심 생검이 가지는 진단의 일부 부정확성
을 배제하기 위하여 시행한 두번째 중심 생검에서는 "변성된 조직을 동반한 호산성 과립세포(oxyphilic cells with degenerated tissue)"로 보고되었다(Fig. 3). 두 번의 생검 결과와
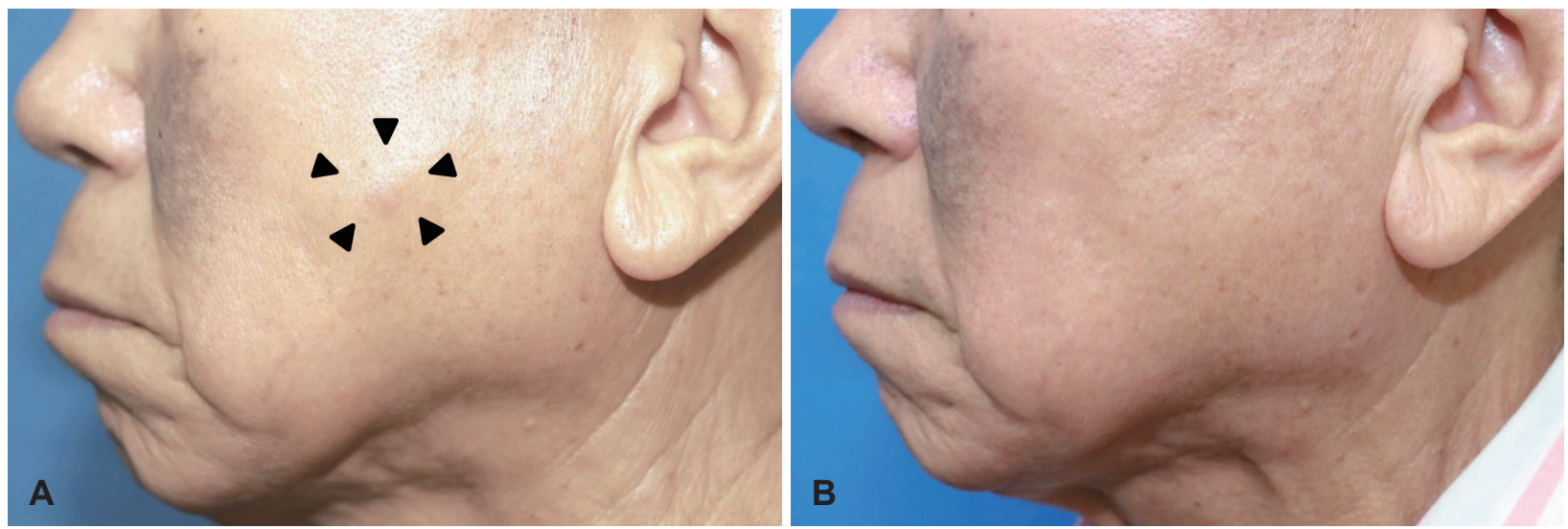

Fig. 1. Facial photographs before $(A)$ and after treatment (B). It shows a $1.6 \times 1.4 \mathrm{~cm}$ sized well-margined ovoid mass on right mid-cheek area (arrowheads) (A). It shows no definite delineation of mass in same region (B).
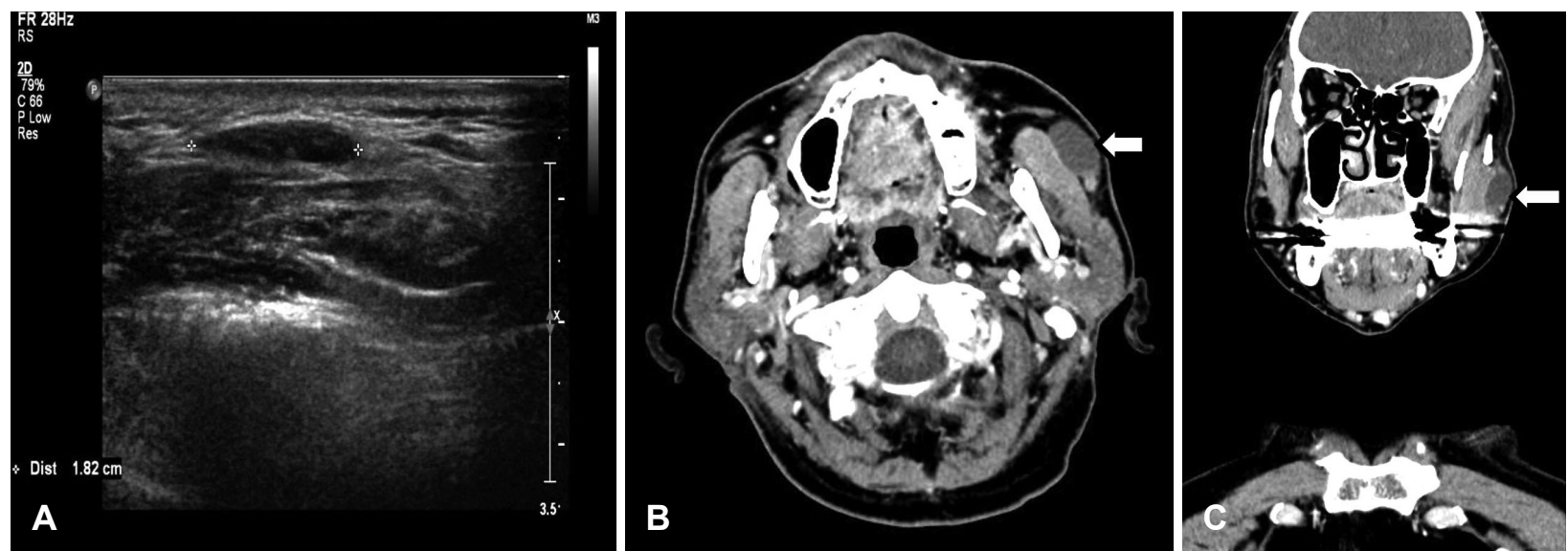

Fig. 2. Initial imaging studies. Transverse scan of neck ultrasonography reveals $1.8 \times 1.4 \times 0.4 \mathrm{~cm}$ sized well-margined ovoid hypoechoic mass superficial to masseter muscle (asterisks) (A). Enhanced neck CT scan reveals non-enhanced low density mass on right mid-cheek area (arrows) (B, C).

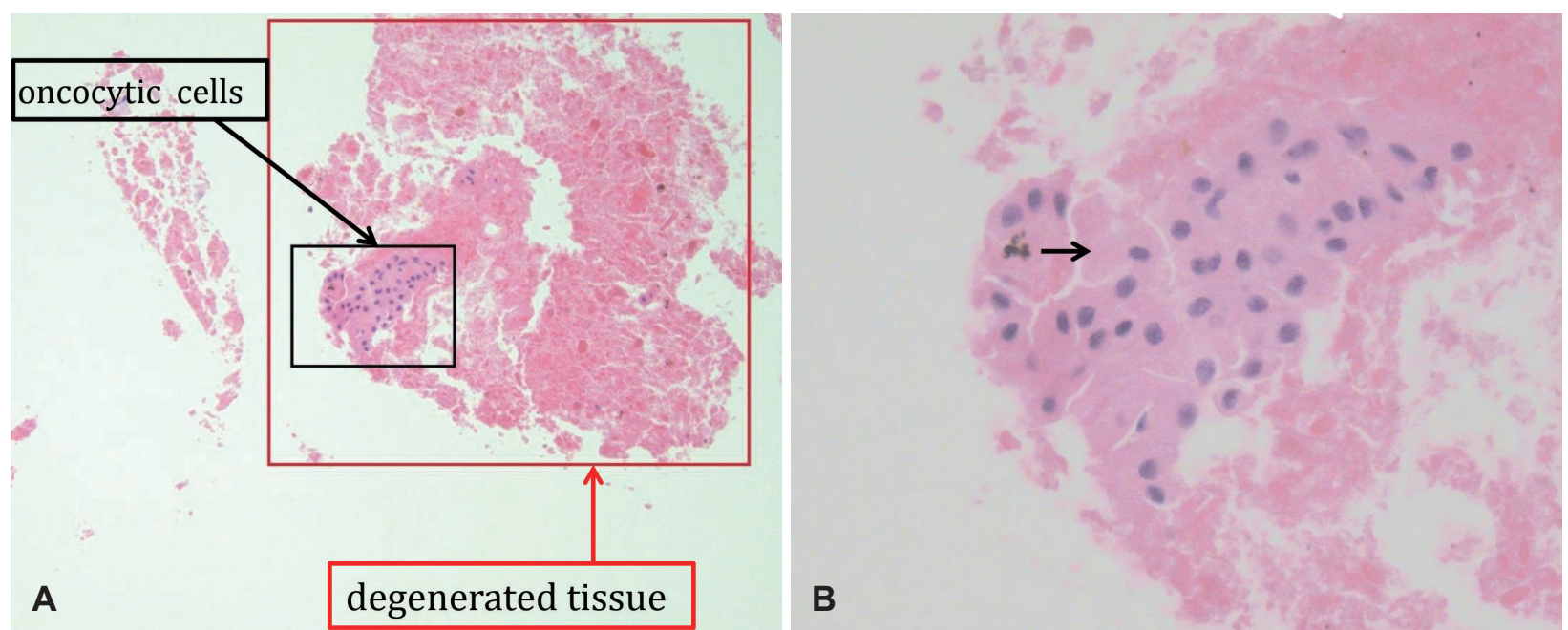

Fig. 3. Findings of core needle biopsy. Each of color box means the areas of oxyphilic cells and degenerated tissue $(H \& E$ stain, $\times 100)$ (A). It shows a typical oxyphilic cell (arrow) (H\&E stain, $\times 400)(B)$. H\&E: hematoxylin \& eosin. 
영상 소견 등을 종합해서 부이하선에 발생한 양성 낭종성 종 물로 진단하였다.

시술은 5 12 MHz의 선형 탐촉자가 장착된 iU22 필립스 초음파시스템(Philips Healthcare, Bothell, WA, USA)을 사 용하였다. 환자의 안면부를 우측으로 돌리고, 피부 소독 이후 $2 \%$ 리도케인으로 좌측 협부를 국소 마취하고 초음파 탐촉자 와 평행하게 20게이지 주사침을 낭종 내부로 넣어서 중심에 위치시키고, 내부의 액체를 최대한 많이 흡인하였다. 내부의 분비물 제거를 위하여 흡인한 양 $80 \%$ 정도의 생리식염수를 주입 후, 재흡인하였다. $99.9 \%$ 에탄올(Fisher Scientific Korea Ltd., Seoul, Korea)을 처음 흡인한 양의 $90 \%$ 정도로 주 입하고, 주사침 제거와 동시에 주입된 에탄올 유출을 방지하 기 위해서 3 분 정도 압박하고, 초음파로 주입액 유출 및 합병 증 등의 여부를 관찰했다. 환자는 에탄올 주입시 좌측 협부에 경한 작열감과 압통 등을 호소하였다. 시술 1 주 후에도 좌측 협부의 압통과 개구장애 등을 호소하여, 전산화단층촬영을 시행하였다. 낭종은 소실되고 융합된 낭벽만 관찰되었지만, 좌측 교근이 비균질하게 조영 증강되었다(Fig. 4A). 에탄올 주입 후 발생한 “교근염”으로 진단하고 소염진통제, 우측으로 저작 및 교근 주변에 물리치료 등을 시행하였고, 시술 4주 후 에는 증상이 크게 호전되었다. 주입술 10 주 후 시행한 전산화 단층촬영에서 교근의 조영 증강은 소실되고, 융합된 낭벽은 이전 소견과 유사하였다(Fig. 4B). 신체 검사에서도 정상 개 구량을 보이고, 협부 종물은 촉지되지 않았다(Fig. 1B). 시술 11 개월이 지난 현재까지 초음파와 신체검사 소견 등에서 특
별한 변화 없이 추적관찰 중이다.

\section{고 찰}

부이하선은 해부학적으로 주이하선과 분리되어 교근의 천 층에서 이하선관과 협골 사이에 위치하는 이하선 조직으로 $20 \%$ 정도에서 존재한다. ${ }^{1)}$ 이곳에 발생하는 종양은 전체 이하 선 종양의 $7 \%$ 미만이고, 양성은 다형선종, 악성은 점액표피 양 암종이 가장 흔하다.,4) 가장 흔한 임상 증상은 이하선관의 주행과 일치하는 중간 협부의 무통성 종물이며, 표피 낭종, 지방종, 혈관종, 타석증, 림프절 병증, 신경인성 종양 및 섬유 종 등과 감별해야 한다. ${ }^{5)}$ 부이하선에 발생한 낭종의 보고는 극히 드물어 저자들의 검색으로는 수술로 치료한 3예의 영문 보고만 존재한다. ${ }^{6-8)}$ 부이하선 종물은 이하선보다 전방에 위 치해서 다른 종양으로 오인하기 쉬우며, 생검 시 타액루 및 안면신경 마비 등이 발생할 수 있어 주의를 요한다.2)

두경부 양성 종양의 비수술적 치료에는 경화요법 및 고주 파 절제술 등이 대표적이다. 이때 사용되는 초음파 장비는 두 경부 종물의 평가에 적합한 선형 탐촉자를 탑재한 도플러 기 능이 되는 고해상도 초음파가 적합하고, 시술 준비, 시술 중과 직후에 숙련된 보조인력의 조력도 중요하다. 또한 흡인 및 약 물의 주입 시 삼방향 캐눌라(three way cannula)를 사용하 면, 더 정확하고 신속한 시술이 가능하다."

경화요법은 에탄올과 OK-432(Picibanil ${ }^{\circledR}$, Chugai Pharmaceutical Co., Ltd., Tokyo, Japan) 등이 가장 흔하게 사용
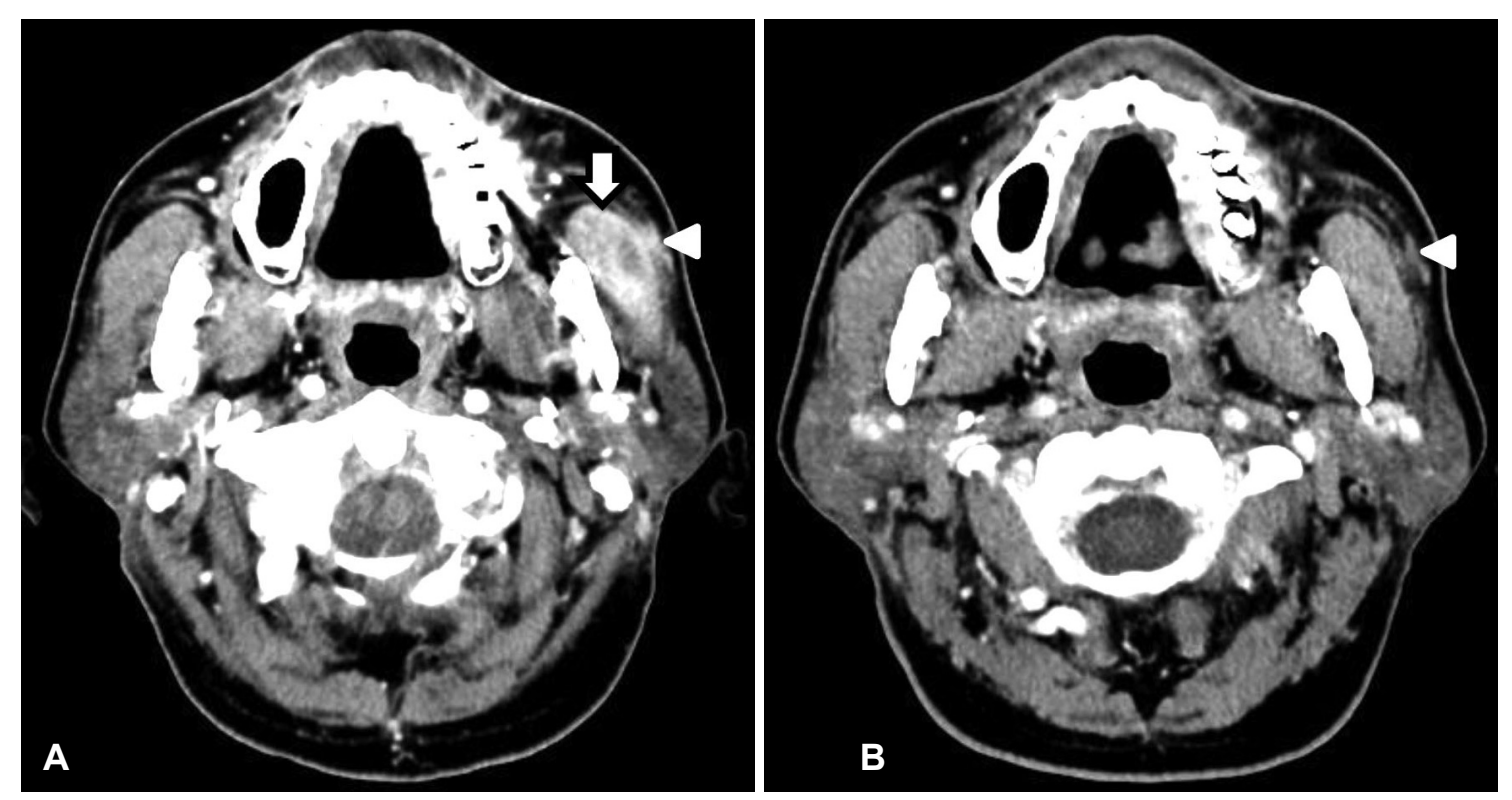

Fig. 4. Post-treatment neck CT scans after one week (A) and ten weeks (B). It shows a collapsed cystic wall (arrowhead) with heterogenous enhancement of left masseter muscle (arrow) (A). It reveals no significant interval change of fused cystic wall (arrowhead) with normal density in left masseter muscle (B). 
되고, 림프관종, 갑상샘 낭종, 새열낭종, 하마종 및 혈관종 등 에서 양호한 치료 성적이 보고되어 있다. ${ }^{3)} \mathrm{OK}-432$ 는 낭종에 염증 반응을 일으켜 내피의 투과성을 증가시켜서 낭종의 크 기를 감소시키지만, ${ }^{10)}$ 현재는 한국희귀·필수의약품센터를 통 해서만 제한적으로 약품을 구할 수 있다.

에탄올은 세포의 탈수, 단백질 괴사, 섬유화 및 미세혈관의 혈전 등을 일으켜서 낭종의 크기를 감소시키며, 재시술이 용 이하고, 경제적이다. ${ }^{9)}$ 그러나 합병증이 $\mathrm{OK}-432$ 보다 흔해서 발열, 통증, 혈종, 조직 괴사, 신경 마비 및 전신 흡수에 의한 저혈압, 호흡 곤란, 부정맥 등이 발생할 수 있다. ${ }^{9,11)}$ 이런 합병 증을 최소화하기 위해서는 정확한 부위에 주입하고, 체내에 흡수되는 에탄올 양을 최소화하기 위해 주입된 양이 최대 $10 \mathrm{cc}$ 를 넘지 않아야 하며, 주입 후 일정 시간 낭종을 압박 하여 주입액의 낭 외 유출을 최소화해야 한다. ${ }^{11)}$ 일반적으로 경화제를 주입 후 낭종 안에 그대로 두지만, 합병증을 우려하 여 주입 후 수분 뒤에 다시 흡입하여 제거하는 술자도 있다. 주입 시 바늘의 위치가 신경과 근접할 것으로 예상되는 곳은 바늘을 세워서 주입하는 것이 보다 안전하다. ${ }^{11)}$ 본 증례에서 에탄올 주입 시 압통과 작열감이 있고, 근염이 발생한 것은 에탄올의 국소 자극 증상 이외에 낭 외로 미세하게 유출되어 발생한 것으로 추정된다.

경화 요법의 효과를 극대화하기 위해서는 종물의 내용물 을 최대한 많이 흡입하고, 내부 부유물이 잔존하지 않게 세척 하고, 낭벽 전체에 주입액이 묻어야 하며, 주입물의 유출을 최소화해야 한다. ${ }^{12)}$ 경화 치료 후에는 재발의 가능성이 있으 므로 초음파 추적관찰이 중요하다. 이때 치료 후 병변은 낭벽 주변의 육아형성 및 섬유화 등으로 초음파 소견이 저에코, 석 회화 및 불분명한 경계 등을 보일 수 있으므로 판독에 주의 를 요한다. ${ }^{13)}$

부이하선 종물의 치료는 수술이 원칙이며, 안면신경 마비 및 타액루 같은 합병증을 예방하기 위해 종물 직 상방으로의 직접 절개에 의한 것보다 이하선 천엽절제술이 더욱 추천된 다. ${ }^{5)}$ 본 증례처럼 고령의 불량한 전신 상태이고, 조직검사 및 영상 소견 등에서 양성 낭종성 병변이 저명한 경우에는 경화 요법을 시행할 수 있다고 사료된다.

저자들은 본 증례를 통해 중협부의 표층 종물의 진단 시 반드시 부이하선 종양을 고려해야 하며, 양성 낭종으로 확진 된 경우에 환자에 따라서 초음파 유도 하 에탄올 주입술이 대체적 치료로 적용될 수 있다고 생각한다. 향후 유사 증례의 채집과 다기관 연구를 통해서 에탄올 경화요법의 표준화된 시술 방법 및 두경부 낭성질환의 치료 결과에 대한 지속적인
연구가 필요하다고 사료된다.

\section{Acknowledgments}

None.

\section{Author Contribution}

Conceptualization: Seung Woo Kim. Formal analysis: Beom Mo Koo. Investigation: Beom Mo Koo. Methodology: Moon Seung Beag. Supervision: Seung Woo Kim. Validation: Mi Ji Lee. Visualization: Mi Ji Lee. Writing — original draft: Moon Seung Beag. Writing—review \& editing: Seung Woo Kim.

\section{ORCID}

Seung Woo Kim https://orcid.org/0000-0002-7931-6977

\section{REFERENCES}

1) Toh H, Kodama J, Fukuda J, Rittman B, Mackenzie I. Incidence and histology of human accessory parotid glands. Anat Rec 1993;236(3): 586-90.

2) Lukšić I, Suton P, Rogić M, Dokuzović S. Accessory parotid gland tumours: 24 years of clinical experience. Int J Oral Maxillofac Surg 2012;41(12):1453-7.

3) Lee JH, Yoon SW, Park HS, Kang MK, Lee JH, Jang AL, et al. Efficacy of percutaneous ethanol injection for benign neck cyst. Korean J Otorhinolaryngol-Head Neck Surg 2016;59(6):448-52.

4) Newberry TR, Kaufmann CR, Miller FR. Review of accessory parotid gland tumors: Pathologic incidence and surgical management. Am J Otolaryngol 2014;35(1):48-52.

5) Choi EC, Koh YW, Choi JJ, Chung SH, Hong HJ, Han SJ. Surgical treatment of primary and metastatic malignant tumors of the accessory parotid gland. Korean J Otolaryngol 2001;44(3):337-40.

6) Lee AD, Mima T, Morimoto Y, Takigawa Y. Salivary duct cyst of accessory parotid gland in contact with the temporomandibular joint. Oral Surg Oral Med Oral Pathol Oral Radiol 2018;125(4): e108-12.

7) Lin DT, Coppit GL, Burkey BB, Netterville JL. Tumors of the accessory lobe of the parotid gland: A 10-year experience. Laryngoscope 2004;114(9):1652-5.

8) Polayes IM, Rankow RM. Cysts, masses, and tumors of the accessory parotid gland. Plast Reconstr Surg 1979;64(1):17-23.

9) Ahn D, Kim H, Lee JH, Sohn JH. Feasibility of surgeon-performed ultrasound-guided ethanol ablation in benign cystic thyroid nodules: Preliminary report. Korean J Otorhinolaryngol-Head Neck Surg 2015;58(4):261-6.

10) Wiegand S, Eivazi B, Zimmermann AP, Sesterhenn AM, Werner JA. Sclerotherapy of lymphangiomas of the head and neck. Head Neck 2011;33(11):1649-55.

11) Oh SK, Lee JY, Lee DH, Moon IH, Kwon KN, Park KN, et al. The utility of sono-guided sclerotherapy for benign thyroid cyst: Prospective study. Korean J Otorhinolaryngol-Head Neck Surg 2012;55(12):777-81.

12) Kim KH, Sung MW, Roh JL, Han MH. Sclerotherapy for congenital lesions in the head and neck. Otolaryngol Head Neck Surg 2004; 131(3):307-16.

13) Park NH, Kim DW, Park HJ, Lee EJ, Park JS, Park SI, et al. Thyroid cysts treated with ethanol ablation can mimic malignancy during sonographic follow-up. J Clin Ultrasound 2011;39(8):441-6. 